\title{
2016 South Florida Beef Forage Survey Results ${ }^{1}$
}

\author{
Laura Bennett, Jonael Bosques, Sarah Bostick, Lauren Butler, Sonja Crawford, Taylor Davis, \\ Christa Kirby, Colleen Larson, Philipe Moriel, Chris Prevatt, Brent Sellers, Maria Silveira, Aaron \\ Stam, Bridget Stice, Joao Vendramini, and Lindsey Wiggins ${ }^{2}$
}

\section{Introduction}

The UF/IFAS South Florida Beef Forage Program (UF/ IFAS SFBFP) is composed of county Extension faculty and state specialists. The members, in conjunction with the UF/ IFAS Program Evaluation and Organizational Development unit, created a survey in 1982, which is used to evaluate ranch management practices to determine benchmarks in cattle production and pasture management. The survey is updated and distributed every five years to ranchers in 14 south Florida counties: Charlotte, Collier, DeSoto, Glades, Hardee, Hendry, Highlands, Hillsborough, Lee, Manatee, Martin, Okeechobee, Polk, and Sarasota. There were 112 anonymous responses.

According to the 2017 National Agriculture census, Florida has 21,469 cattle ranches with $1,635,745$ head of cattle. The surveyed area accounts for 6,723 cattle ranches and 762,771 head of cattle $(47 \%)$ of the state's herd.

\section{Characteristics of Beef Operations in South Florida}

Type of Beef Operations: The beef cattle industry in south Florida is primarily commercial. A small percentage of ranchers ran both purebred and commercial herds (Figure $1)$.

\section{Beef Operations}

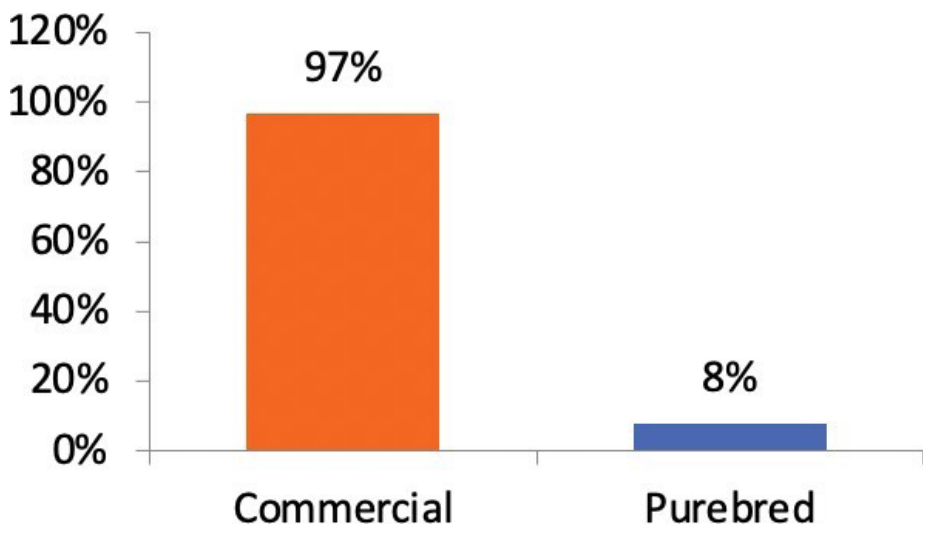

Figure 1. Distribution of commercial and purebred beef operations. Credits: Sonja Crawford and Lindsey Wiggins

1. This document is SS-AGR-407, one of a series of the Agronomy Department, UF/IFAS Extension. Original publication date July 2021. Visit the EDIS website at https://edis.ifas.ufl.edu for the currently supported version of this publication.

2. Laura Bennett, multi-county livestock agent I, UF/IFAS Extension Hernando, Pasco, and Sumter Counties; Jonael Bosques, county Extension director, livestock agent, UF/IFAS Extension Hardee County; Sarah Bostick, agriculture and natural resources agent, UF/IFAS Extension Sarasota County; Lauren Butler, county Extension director, livestock agent II, UF/IFAS Extension Okeechobee County; Sonja Crawford, 4-H coordinator, livestock agent II, UF/ IFAS Extension Hendry County; Taylor Davis, livestock and natural resources agent, UF/IFAS Extension Highlands County; Christa Kirby, livestock Extension agent IV, UF/IFAS Extension Manatee County; Colleen Larson, regional dairy agent, UF/IFAS Extension Okeechobee, Highlands, DeSoto, and Hardee Counties; Philipe Moriel, associate professor, beef cattle nutrition and management, UF/IFAS Range Cattle Research and Education Center; Chris Prevatt, state specialized Extension agent II, beef cattle and forage enterprise budgeting and marketing, UF/IFAS RCREC; Brent Sellers, professor, Agronomy Department, and center director, UF/IFAS RCREC; Maria Silveira, professor, soil fertility and water quality, Department of Soil and Water Sciences, UF/IFAS RCREC; Aaron Stam, Extension agent I, Seminole Tribe of Florida; Bridget Stice, Extension agent, UF/IFAS Extension Polk County; Joao Vendramini, professor, Agronomy Department, UF/IFAS RCREC; and Lindsey Wiggins, livestock agent, UF/IFAS Extension Hendry, Glades, Charlotte, Lee, and Collier Counties; UF/IFAS Extension, Gainesville, FL 32611.

The Institute of Food and Agricultural Sciences (IFAS) is an Equal Opportunity Institution authorized to provide research, educational information and other services only to individuals and institutions that function with non-discrimination with respect to race, creed, color, religion, age, disability, sex, sexual orientation, marital status,

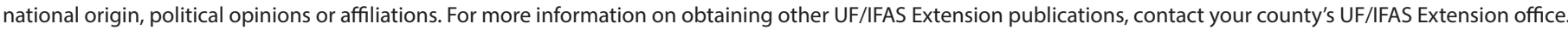
U.S. Department of Agriculture, UF/IFAS Extension Service, University of Florida, IFAS, Florida A \& M University Cooperative Extension Program, and Boards of County Commissioners Cooperating. Nick T. Place, dean for UF/IFAS Extension. 
Business Structure of the Ranch: Fifty-three percent (53\%) of ranches are sole proprietorship whereas $30 \%$ are corporate-owned and $17 \%$ operate as a partnership. (Some respondents operated in multiple business structures.)

Ranchers' Source of Income: Sixty-eight percent (68\%) of ranchers receive income from another profession.

Years in Cattle Business: Survey respondents have been in the business for an average of 39 years.

Plans for the Next Five Years: Ninety-five percent (95\%) of ranchers plan to maintain or increase the size of their operations in the next five years (Figure 2).

\section{Plans for the Next Five Years}

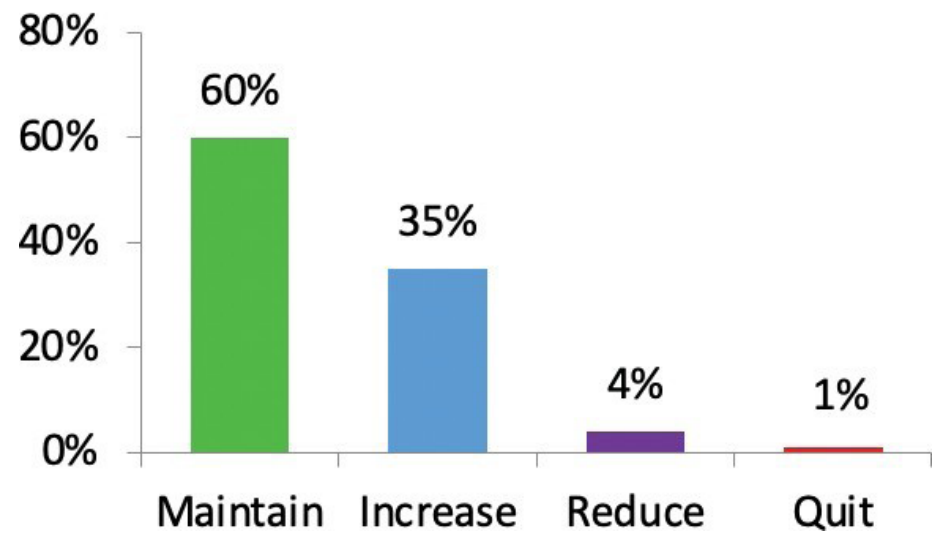

Figure 2. Producer plans for the next five years.

Credits: Sonja Crawford and Lindsey Wiggins

\section{Reproduction}

Pregnancy Rates: Average pregnancy rates are shown in Figure 3. Pregnancy rates are calculated by dividing the number of females exposed to bulls by the number of females determined pregnant through pregnancy diagnosis methods.

\section{Pregnancy Rates}

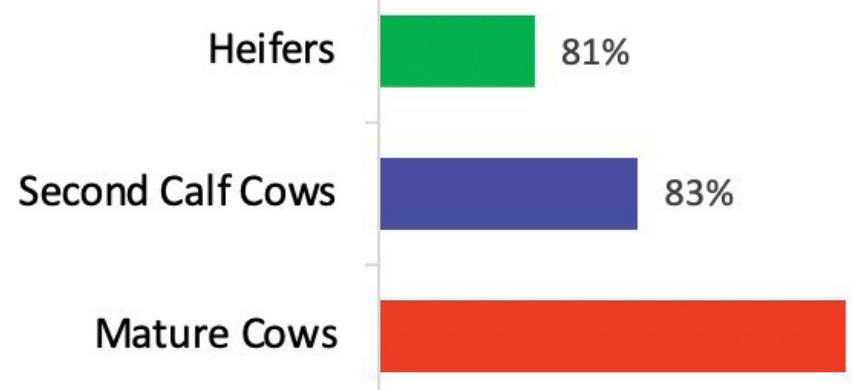

$87 \%$

Figure 3. Average pregnancy rates.

Credits: Sonja Crawford and Lindsey Wiggins
Pregnancy Checking: Fifty-one percent (51\%) of ranchers checked for pregnancy. Veterinarians (70\%) checked for pregnancy most often, followed by ranch employees (55\%). Rectal palpation (86\%) was the most used method, followed by ultrasound (38\%) and blood testing used by veterinarians (14\%). Some respondents used multiple methods and received assistance from employees and veterinarians. Twenty-nine percent (29\%) of respondents attended a reproductive management (palpation) school.

Breeding Season: Sixty-nine percent (69\%) of ranchers used a controlled breeding season, whereas $31 \%$ exposed females to bulls year-round.

Weaning Rate: Weaning rate for first-calf heifers was $81 \%$. Eighty-three percent (83\%) of the second-calf cows weaned a calf. The mature cow weaning rate was $87 \%$.

Calf Loss: Calf loss was estimated at 3\% gestational loss, 3\% predators, and $2 \%$ disease.

Artificial Insemination: Seventeen percent (17\%) of the ranchers who participated in the survey reported that $36 \%$ of their herd were inseminated artificially. Controlled internal drug release (CIDR) was the most used method of synchronization, closely followed by prostaglandin.

Bull Breeds for Heifers: Angus bulls were most used on heifers (Figure 4). Some ranchers indicated using more than one breed.

\section{Bulls Used on Heifers}

\section{$100 \% \quad 88 \%$}

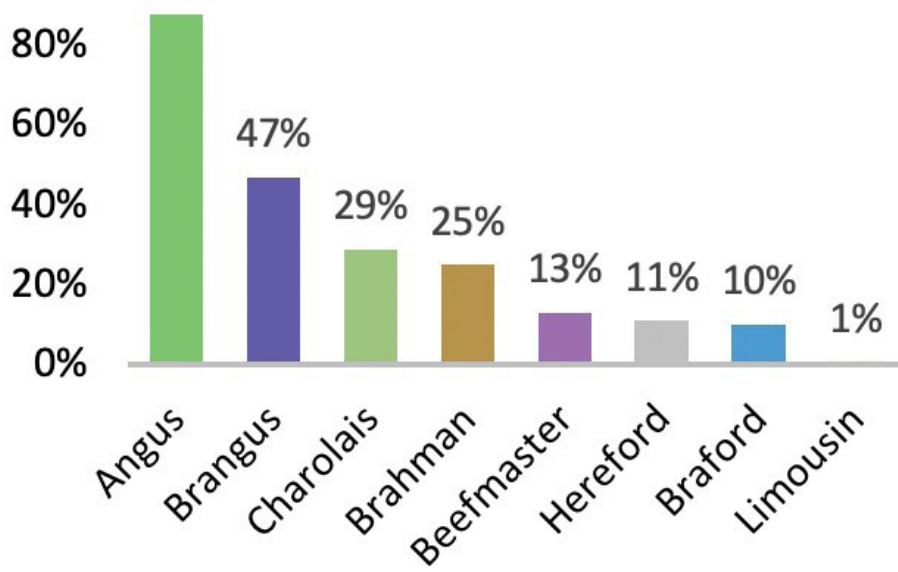

Figure 4. Bull breeds used on heifers.

Credits: Sonja Crawford and Lindsey Wiggins

Bull Breeds for Cows: Angus and Brangus bulls were most frequently used on cows (Figure 5). Some ranchers indicated using more than one breed. 


\section{Bulls Used On Cows}

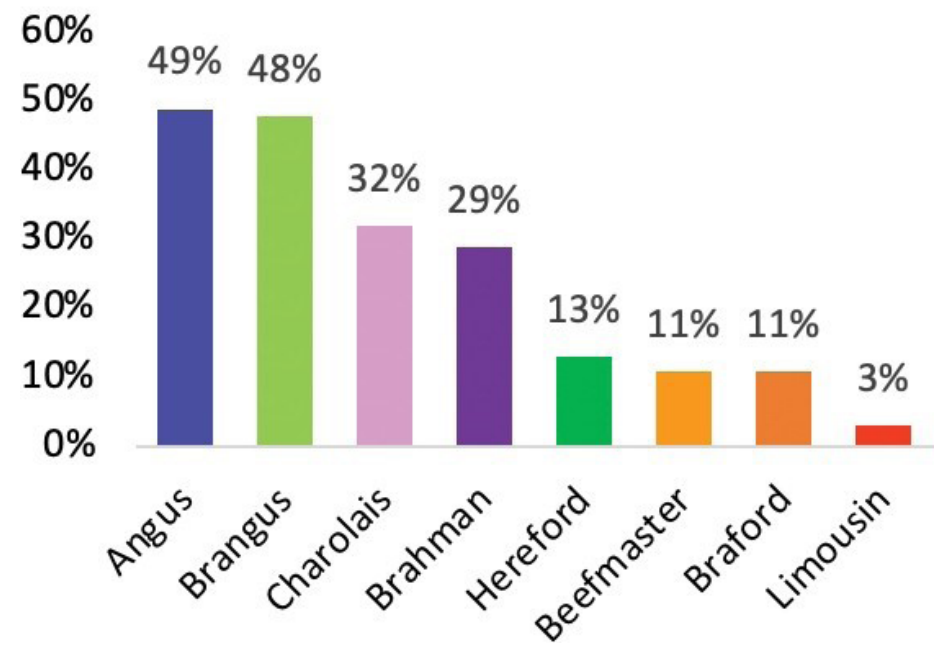

Figure 5. Bull breeds used on cows.

Credits: Sonja Crawford and Lindsey Wiggins

Bull to Heifer Ratio: On average, one bull per 20 heifers.

Bull to Cow Ratio: On average, one bull per 24 cows.

Culled Cows: South Florida ranchers, on average, culled $8 \%$ of their cow herd each year.

Limitations to Reproduction: Producers ranked nutrition as the most significant limitation to reproduction, followed by management and parasites.

Bull Selection: Surveyors ranked 12 attributes they used to select bulls. Birth weight was the most important attribute, followed by bull price. Weaning weight ranked third.

Heifer Management: Fifty-six percent (56\%) of ranchers did not expose heifers to bulls at a date prior to the mature cow herd. Sixty-nine percent (69\%) of operations managed their herd replacements separately from the mature cow herd.

Semen Testing: Figure 6 below indicates how often semen testing occurred for the bulls.

Trichomoniasis Testing: Fifty-one percent (51\%) of ranchers tested for Trichomoniasis, with the majority (61\%) of those testing annually.

Herd Replacements: Eighty-seven percent (87\%) of ranchers raised their own heifers (Figure 7). Of those who purchased replacements, private treaty was preferred most. The livestock market and the FCA Heifer Sale were the next most preferred means of obtaining replacements.

\section{Bull Semen Testing}

Annually; before breeding season
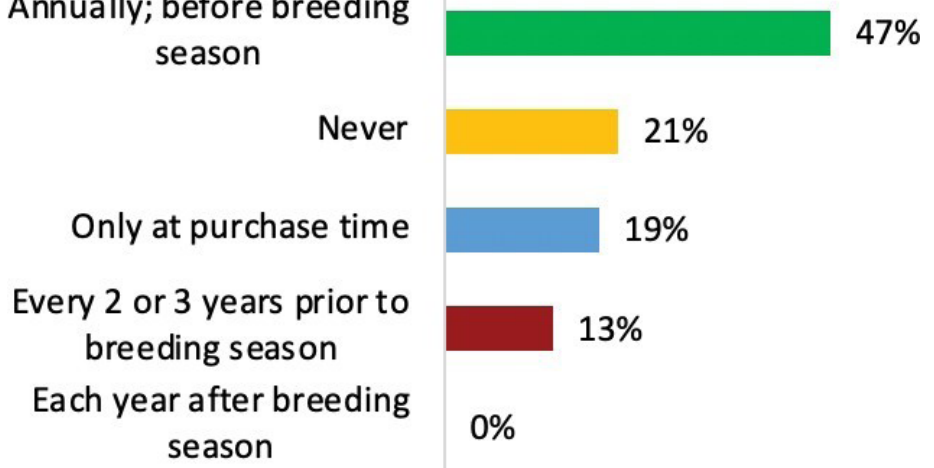

Figure 6. How often bulls are semen tested. Credits: Sonja Crawford and Lindsey Wiggins

\section{Herd Replacements}

$87 \%$

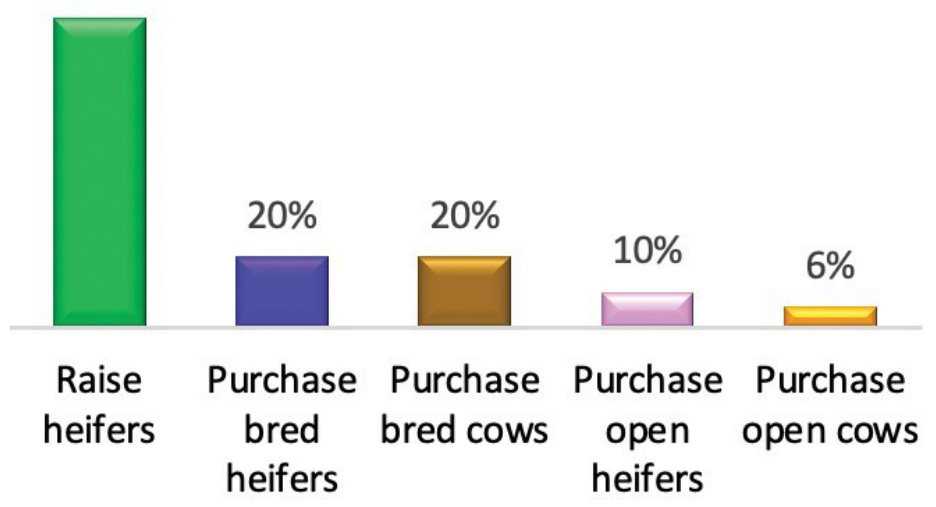

Figure 7. Methods of obtaining herd replacements. Credits: Sonja Crawford and Lindsey Wiggins

Age at Which Heifers First Calve: Sixty-four percent (64\%) of ranchers allowed their heifers to have their first calf at 2 years of age.

\section{Production}

Cow/Calf Identification: Fifty-six percent (56\%) of respondents identified each cow and $37 \%$ of respondents identified each calf with an ear tag, hot iron, or freeze brand.

Beef Herd Records: Sixty-eight percent (68\%) of ranchers used written herd records with $61 \%$ utilizing the records for business analysis and 57\% using the records to select heifers and/or cull cows. Fifty-seven percent (57\%) of those keeping records are using a computerized system.

Annual Cow Cost: Ranchers estimated their cost per cow per year to be $\$ 370$. 


\section{Marketing}

Weaning Age and Weight: Calves were weaned at an average age of 7.6 months. Steer calves averaged 494 pounds and heifer calves averaged 472 pounds.

Calf Marketing Methods: Eighty-two percent (82\%) of beef cattle operations sold their calves through the auction/ livestock market. Many ranchers indicated multiple methods for marketing (Figure 8).

\section{How Producers Market Calves}

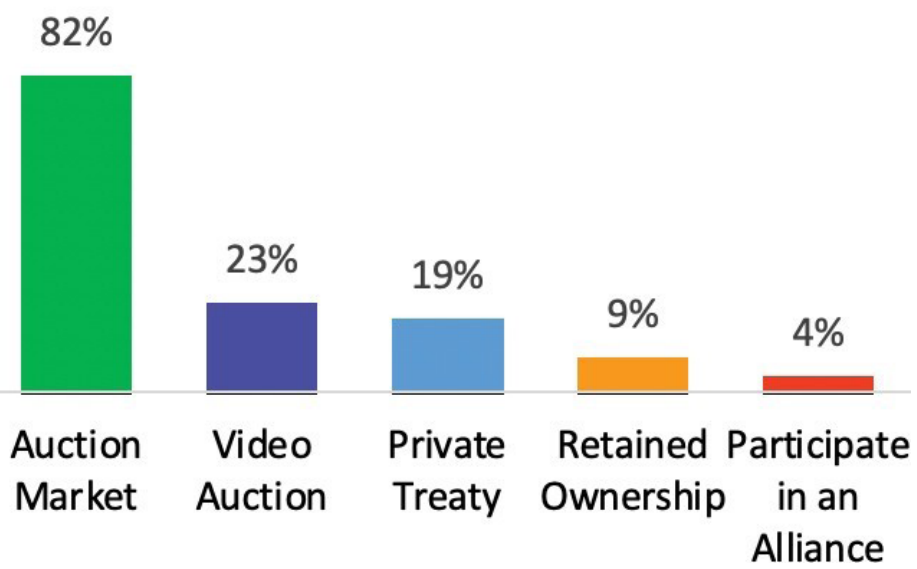

Figure 8. Calf marketing methods.

Credits: Sonja Crawford and Lindsey Wiggins

Marketing Preparation: Various marketing preparations are conducted, with castration $(73 \%)$ being used most (Figure 9).

\section{Herd Health}

External Parasite Control: Ninety-four percent (94\%) of producers control external parasites on their cattle. The pour-on method was the most used among producers in south Florida. Dust bags were the least commonly used. Producers frequently used more than one method to control external parasites (Figure 10).

Liver Fluke Treatment: Survey results indicated $76 \%$ of the producers in south Florida treated the herd for liver flukes.

Internal Parasite Control: Most south Florida beef producers deworm their herd (Figure 11). Pour-on and injectable methods were most frequently used. Paste and gel products were used the least.

Vaccination Program: Figure 12 indicates vaccines used in south Florida.
Calf Practices Before Marketing

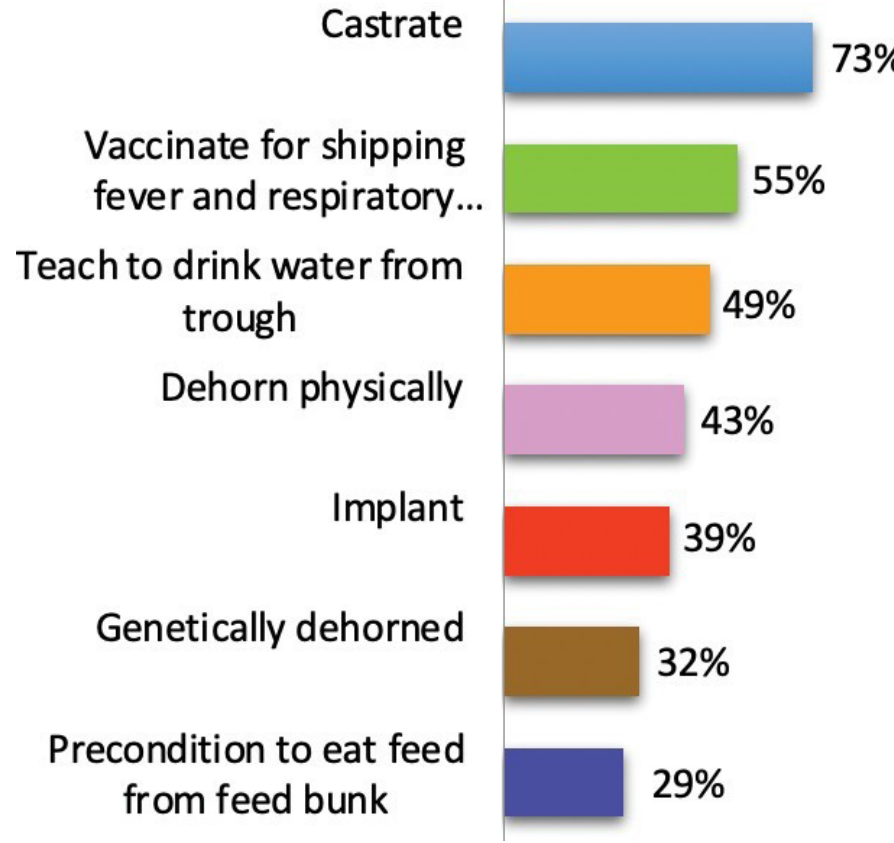

Figure 9. Methods used before marketing calves.

Credits: Sonja Crawford and Lindsey Wiggins

\section{Control Method for External 94\% Parasites}

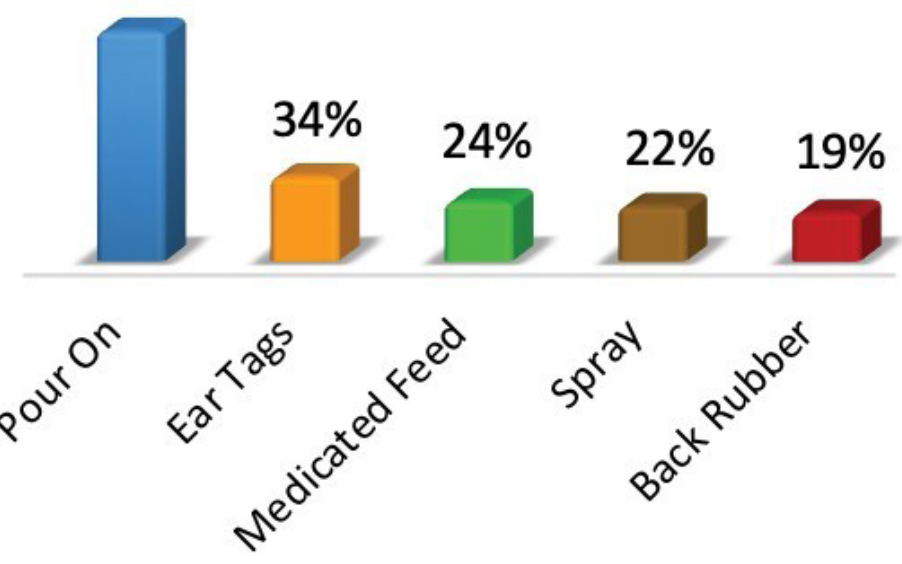

Figure 10. External parasite control methods. Credits: Sonja Crawford and Lindsey Wiggins

\section{Nutrition}

Body Condition Score before Supplementing: Fifty-eight percent (58\%) of ranchers assessed cows' body condition score (BCS) to determine when to begin and end supplementation. Fifty-three percent (53\%) utilized BCS to determine the amount of supplement to feed to the animals. Eighty-five percent (85\%) of ranchers provided supplement to their herd October through May. 


\section{Deworming the Herd}

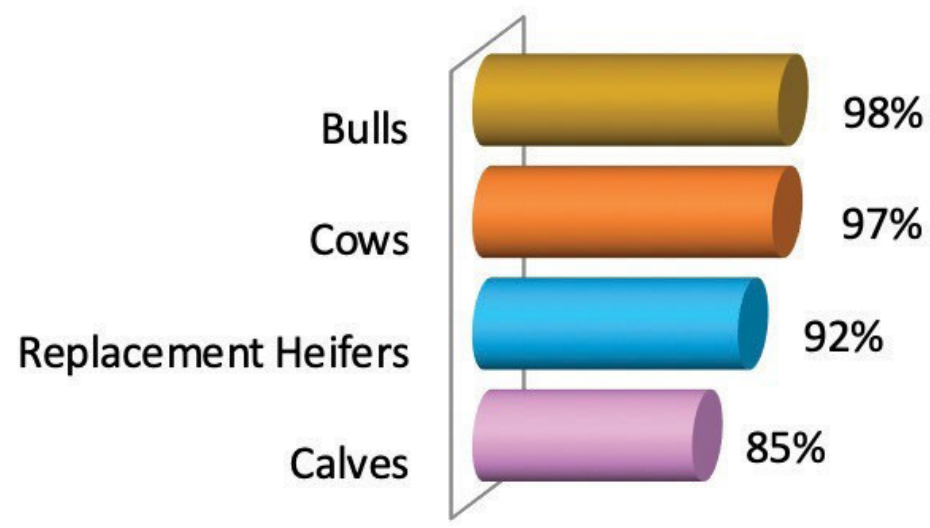

Figure 11. Percent of producers who dewormed their herd. Credits: Sonja Crawford and Lindsey Wiggins

\section{Vaccination Program}

\section{Blackleg \\ Vibrio \\ Lepto}

IBR, BVD, PI3 \& BRSV

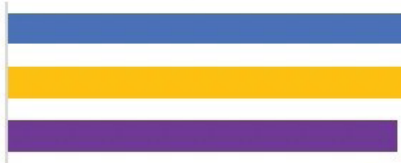

$77 \%$

$76 \%$

$74 \%$

\section{Brucellosis}

Trichomoniasis

Pasteurella

Red Water

Tetanus

Haemophilus somnus

Pinkeye

E. coli

None

Figure 12. Diseases that producers vaccinated against.

Credits: Sonja Crawford and Lindsey Wiggins

Mineral Supplementation: Ninety-three percent (93\%) of producers provided mineral supplementation to their cattle and $91 \%$ of these producers provided mineral all year.

Pasture Analysis: Only 31\% of ranchers reported analyzing their pasture grass for forage quality.

Sources of Winter Supplementation: Operations frequently used more than one form of supplement. Seventy-one percent $(71 \%)$ of the producers used molasses fortified with urea as a protein supplement during the winter months (Figure 13).

Winter Forages Used: Hay and native range were most used as winter forage sources followed by stockpiled forage (Figure 14).
Sources of Winter Protein Supplements

$71 \%$
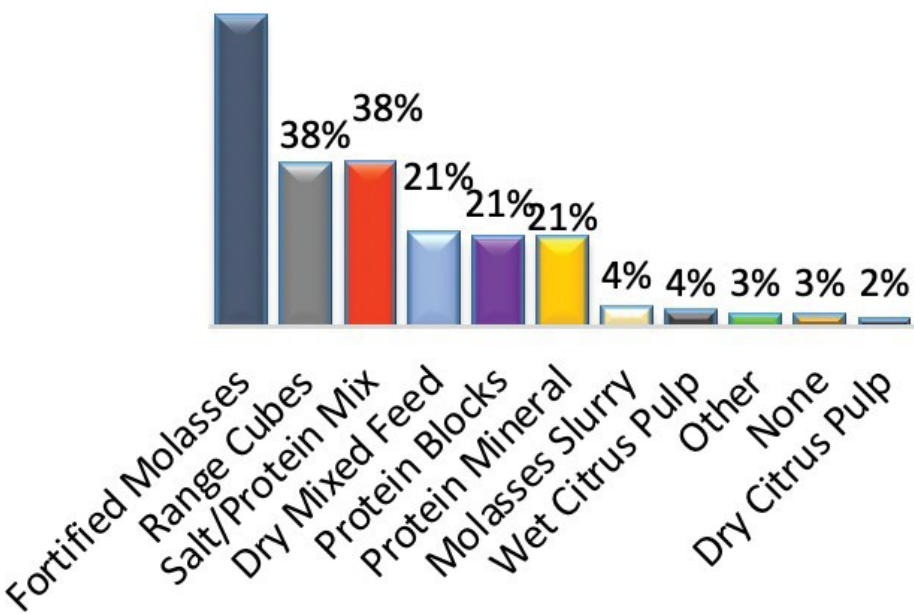

Figure 13. Sources of winter supplementation.

Credits: Sonja Crawford and Lindsey Wiggins

\section{Sources of Winter Forage}

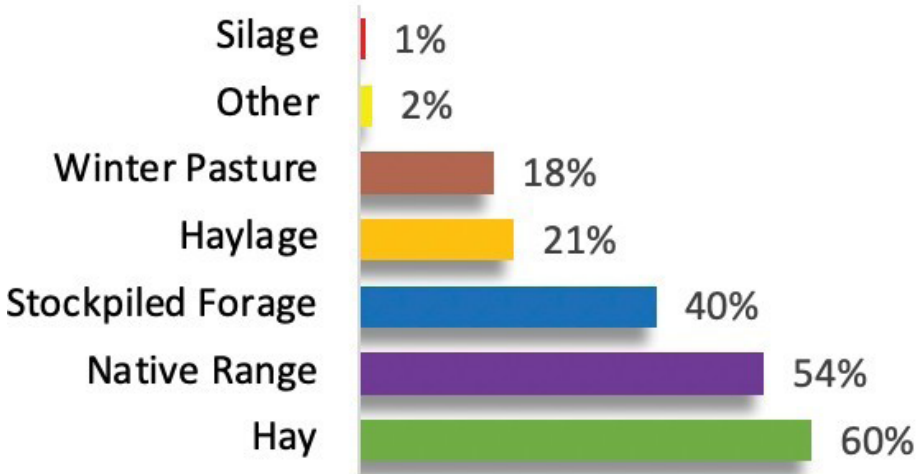

Figure 14. Sources of winter forage.

Credits: Sonja Crawford and Lindsey Wiggins

Analyzing Hay: Only 22\% of south Florida ranchers indicated analyzing their hay or silage for forage quality.

\section{Forage Production}

Pasture and Hay Acreage: Seventy-two percent (72\%) of the acreage is owned and 36\% is leased at an average of $\$ 15 /$ acre/year.

Pasture Irrigation: Fourteen percent (14\%) of pasture acreage is irrigated.

Types of Grazing: Improved pasture (57\%) is the most commonly grazed acreage followed by semi-improved pasture (39\%) then native range (36\%). 
Lime/Fertilizer Application: Eighty-five percent (85\%) of the respondents fertilized their pasture and hay fields with $60 \%$ applying lime.

Types of Forage: Bahiagrass is the most used forage (Figure 15).
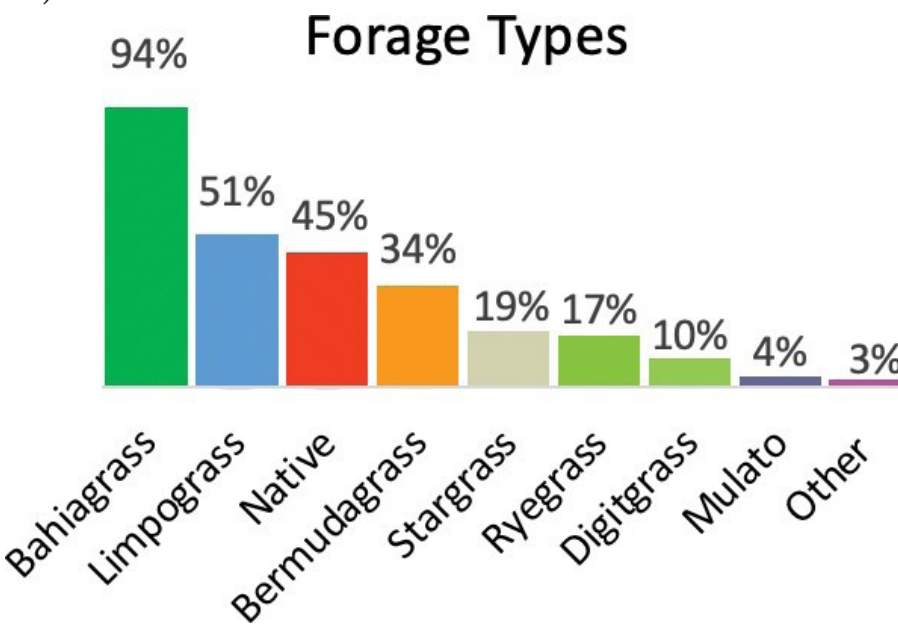

Figure 15. Forage types.

Credits: Sonja Crawford and Lindsey Wiggins

Types of Legumes: Producers identified Aeschynomene as the most used legume (Figure 16).

\section{Legume Type}

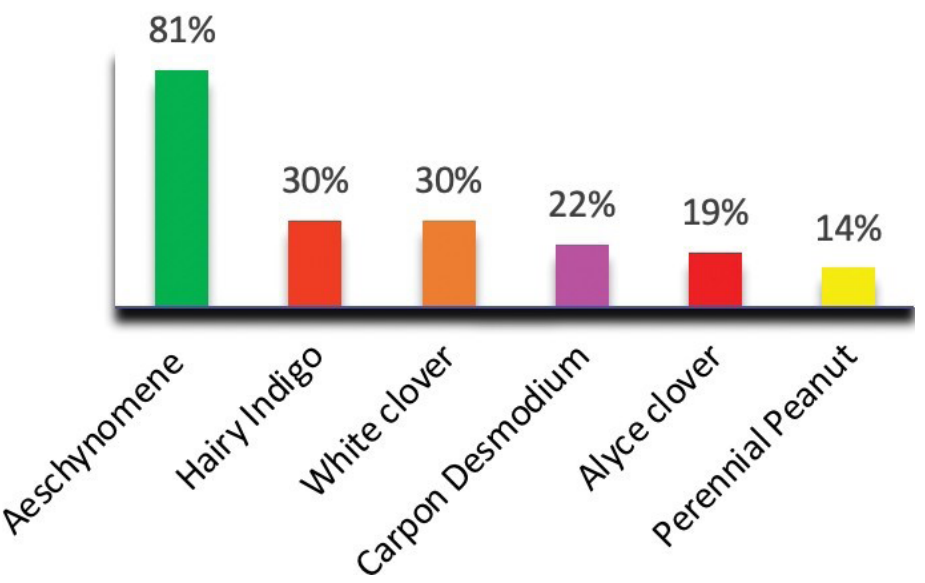

Figure 16. Types of legumes.

Credits: Sonja Crawford and Lindsey Wiggins

Hay Production: Forty-two percent (42\%) of respondents produced hay and 13\% irrigated their hay fields.

Silage or Haylage Production: Eighteen percent (18\%) of survey respondents produced silage or haylage.

Stockpiled Limpograss: Twenty-one percent (21\%) of survey respondents stockpiled limpograss forage.

Rotational Grazing: Eighty-four percent (84\%) of producers rotationally grazed their pasture.
Mole Cricket Pasture Damage: Twenty-six percent (26\%) of producers reported damage from mole crickets.

Organic Waste: Twelve percent (12\%) of ranchers used organic waste on their pasture (sludge, biosolids, poultry litter, etc.) as fertilizer. One hundred percent (100\%) of ranchers noticed improved forage production when it was applied, with $31 \%$ recognizing increased soil $\mathrm{pH}$ and increased weed production.

Troublesome Weeds: Producers ranked ten troublesome weeds. Tropical soda apple ranked as the most troublesome, followed by smutgrass. Dogfennel ranked third.

Weed Control Methods: Mowing or chopping is most commonly employed to combat weeds (89\%) (Figure 17).

\section{IMethods ot Weed Control Used}

\section{$89 \%$}

\section{$87 \%$}

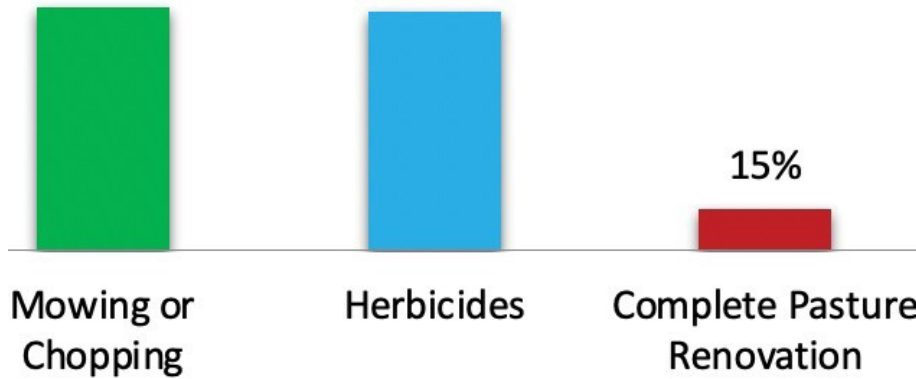

Figure 17. Weed control methods.

Credits: Sonja Crawford and Lindsey Wiggins

\section{Environment}

Ecosystem Service Provided: Eighty-six percent (86\%) of ranchers have open water areas on their ranch that provide quality drinking water to resident wildlife and valuable habitat for aquatic plants and animals. Seventy-three percent $(73 \%)$ of these ranchers provided water troughs for their cattle to drink from.

Nutrient Management: Eighty-four percent (84\%) of survey respondents do not feed mineral, hay, or supplements within 200 feet of the open water areas.

Water Quality Manual: Sixty-three percent (63\%) of ranchers utilized the Water Quality Best Management Practices for Cow/Calf Operations in Florida manual.

\section{Additional Information}

UF/IFAS Extension: Ninety-six percent (96\%) of the producers indicated that the service of UF/IFAS Extension to Florida's beef industry was satisfactory. 
Information Sources: Respondents received information on beef production and/or management from the sources listed in Figure 18, with some ranchers using multiple sources.

\section{Where Producers Receive Information}

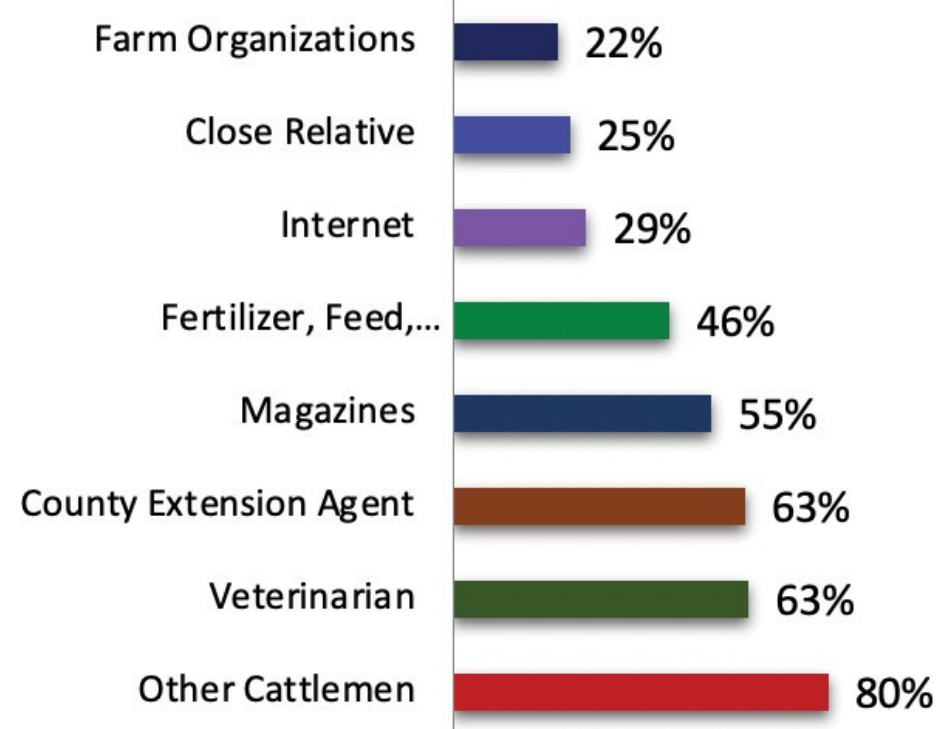

Figure 18. Information sources for producers.

Credits: Sonja Crawford and Lindsey Wiggins

Problems Facing the Cattle Industry: South Florida cattle producers ranked ten problems facing the beef cattle industry. Governmental regulations ranked as the most important, followed by environmental issues. The price the rancher received for calves was the third most important concern.

For more information and to compare this data with previous surveys, visit https://edis.ifas.ufl.edu/ topic_beef_cattle_forage. 